\title{
Quality Changes during Ice Storage of Acetes Species
}

\author{
Utkarsha Keer $^{1}$, Hina Alim², Martin Xavier ${ }^{1}$ and A.K. Balange ${ }^{1 *}$ \\ ${ }^{1}$ Department of Post-Harvest Technology, ICAR-Central Institute of Fisheries Education, \\ Versova, Mumbai- 400 061, India \\ ${ }^{2}$ Department of Life Sciences, University of Mumbai, Kalina, Santacruz (E), \\ Mumbai- 400 098, India \\ *Corresponding author
}

\section{A B S T R A C T}

\section{Keywords \\ Acetes, Ice storage, Quality, Proximate composition, \\ Monounsaturated fatty acids (MUFA), Poly unsaturated fatty acids (PUFA)}

Article Info

Accepted:

14 December 2017

Available Online:

10 January 2018
Acetes is a good source of protein and is very low in fat and calories, making it a healthy food of choice for consumers but due to small in size it degrades faster by the action of microbes and enzymes. However, there is no information about the quality changes of Acetes during icing with reference to proximate composition, fatty acid profile, mineral profile and other biochemical changes. Therefore, the present investigation has been undertaken and the results of ice storage study of Acetes revealed that proximate composition remained constant up to 6 days and it slightly changed during 11 days of storage period. Increase in the percentage of saturated fatty acid with slight reduction in monounsaturated fatty acids (MUFA) and poly unsaturated fatty acids (PUFA) was observed during ice storage. The levels of minerals like $\mathrm{Fe}, \mathrm{Zn}, \mathrm{P}, \mathrm{Ca}$ and $\mathrm{Na}$ also decreased on $9^{\text {th }}$ day of ice storage. Sensory scores of Acetes for all attributes also declined with increase in ice storage. From present study it can be concluded that Acetes can be remained in eatable condition up to 11 days of ice storage.

\section{Introduction}

Acetes contributes to about $55.82 \%$ and $78 \%$ of total non-penaeid landing in Gujarat and Maharashtra respectively in India (Anon, 2013). Some species of Acetes such as Acetes indicus, Acetes johni, Acetes sibogae and Acetes japonicas are available along the Indian coast. Acetes indicus is the most common species and is an epipelagic shrimp which inhibits water shallower than $50 \mathrm{~m}$ deep. They can grow maximum up to $15-20$ $\mathrm{mm}$ in body length and have a lifespan of about 3-10 months. In India, it is mainly landed along North - West coast in the states of Gujarat and Maharashtra. Besides this, it is also landed along the coast of Andhra Pradesh, West Bengal and Andaman and Nicobar Islands (Zynudheen et al., 2004). It is a small sized prawn and is abundant in Indian water throughout the year but the peak season is from April-June and October-December in Maharashtra. It mainly comes as by-catch from trawl and dol net fishing.

Although it is landed in bulk, no proper utilization has been done due to its small size. Preservation of Acetes by traditional icing is 
difficult and it degrades faster by the action of enzymes secreted by hepato-pancreas due to which fisherman dump it onboard and is left to deteriorate. Very little quantity of Acetes landed is consumed in fresh form and due to poor handling most of the catch is degraded as it reaches the coast that can be used only as raw material for fishmeal plants.

Acetes is not a targeted catch and is caught as a by-catch in trawl gear. However, dry Acetes contains $15.55 \%$ moisture, $63.76 \%$ protein, $6.03 \%$ fat and $13.62 \%$ ash (Sridhar, 1983). Due to lack of proper storage facility high portion of catch landed is in decomposed form.

Ice storage is the simplest and cheapest method of short term preservation. It is an effective way of reducing spoilage if done quickly, handled carefully and hygienically. The objective is to cool fish as quickly as possible, to as low a temperature as possible, without freezing. The icing of fish is a process by which temperature of a fish is reduced close to but not below freezing point of water $\left(\begin{array}{ll}0 & { }^{\circ} \mathrm{C}\end{array}\right)$. It delays both biochemical and bacteriological processes in fish and consequently prolongs the storage of fish. The main merit of the method is that it provides the maximum possibility of preserving the natural nutritional and functional properties of the fish. Icing cannot prevent spoilage, but the colder the fish the greater the reduction in bacterial and enzyme activity. Shelf life of iced fish depends mainly on the initial quality of fish, method and duration of icing. Icing leads to various changes according to the initial condition of the fish like type and size of fish, type of ice, method of capture and handling, fat content etc. Angel et al., (1985) reported a shelf-life of 8 days for whole $M$. rosenbergii stored in ice. The shelf life of shrimp (P. merguiensis) stored in ice $\left(0{ }^{\circ} \mathrm{C}\right)$ was remained in acceptable condition up to 8 days (Fatima et al., 1988). Nevertheless, there is very limited literatures on the quality changes of Acetes during ice storage particularly in reference to its nutrient changes i.e. minerals and fatty acids. Therefore an attempt has been made in the present investigation to study the quality changes of Acetes during ice storage.

\section{Materials and Methods}

\section{Sample collection}

Fresh Acetes were purchased from Versova fish landing centre. Insulated ice box with ice was used to bring it to the laboratory. Tap water was used for washing the Acetes to remove dirt. Cleaned and washed Acetes was used for the study. About $500 \mathrm{~g}$ of Acetes was packed in polyethene bags and kept in thermocol box with flake ice. Flake ice was used with Acetes in 1:1 ratio. Melt water was changed twice in a day. Ice storage study was carried out up to 14 days at an interval of 3 days of sampling. The samples were subjected for proximate, biochemical, mineral, microbial and sensory evaluation.

\section{Analyses}

\section{Proximate composition}

Proximate composition i.e. moisture, protein, fat and ash contents were analyzed by the standard method as described by AOAC (2000). Differences in weight were recorded after drying the sample (10 g) in hot air oven at $100 \pm 5{ }^{\circ} \mathrm{C}$ overnight to determine the moisture content. The crude protein content was measured by using the micro-Kjeldahl method using Kelplus equipment (Pelican instruments, Chennai, India). Total lipid was estimated by Soxhlet extraction method with diethyl ether as solvent. Ashing was done by incineration in a muffle furnace (CEM Corporation, USA) at $550 \pm 50{ }^{\circ} \mathrm{C}$ until white ash was obtained. 


\section{Biochemical indices}

Tri-methylamine-nitrogen (TMA-N) and total volatile base-nitrogen (TVB-N) was determined based on the method described by Vyncke (1996) using TCA with slight modifications. Peroxide value (PV) value was expressed as meq of $\mathrm{O}_{2} / \mathrm{kg}$ of fat and determined by AOAC (2005) method. Thiobarbituric acid reactive substances (TBARS) were determined as described by Tarladgis et al., (1960) and expressed as mg of malonaldehyde per $\mathrm{kg}$ of sample. The $\mathrm{pH}$ was measured using a digital $\mathrm{pH}$ meter (Eutechtutor pH/ ${ }^{\circ} \mathrm{C}$ meter, Eutech Instruments, Singapore).

\section{Fatty acid profile}

Preparation of fatty acid methyl esters was done according to the method described in AOAC (1995). The methylated fatty acids were separated using GC-MS (QP2010, Shimadzu, U.S.A.) equipped with DB Wax (30 m X $0.25 \mathrm{~mm}$ internal diameter X $0.25 \mu \mathrm{m}$ film thickness) capillary column (Cromlab S. A.). The Carrier gas used was helium. Injector and detector temperatures were set at $250^{\circ} \mathrm{C}$. Injection was performed in split mode (1:15) with an injection volume of $1 \mu \mathrm{l}$ FAME. The initial column temperature was maintained for 2 minutes at $50{ }^{\circ} \mathrm{C}$. The temperature was set to increase at the rate of $10^{\circ} \mathrm{C}$ per minute till the final temperature of $230{ }^{\circ} \mathrm{C}$ reached and to hold at that temperature for 35 minutes. FAME was separated at a constant pressure of $82.5 \mathrm{KPa}$. The peaks were identified by comparing the mass spectra with the mass spectral data base.

\section{Mineral profile}

Minerals were determined by Inductively Coupled Plasma Atomic Emission Spectrometer (ICP-AES) (Model Thermo Electron IRIS INTREPID II XSP DUO,
Germany). Sample was digested in a Microwave Digester (Milestone, Shelton, Italy) and the prepared sample was aspirated into the flame and the corresponding absorption of the characteristic radiation by each element was recorded. Values are expressed in percentage (\%).

\section{Microbial analysis}

Acetes samples were examined for TPC (Total Plate Count) by the method as described by APHA (2001).

\section{Sensory evaluation}

Samples were evaluated by a panel of 10 judges using 9-point Hedonic scale for their sensory characteristics like color, appearance, texture, odour, taste and overall acceptability.

\section{Statistical analysis}

All analyses were carried out in triplicates and subjected to tests. Analysis of variance was performed by one-way ANOVA procedures with the application of Duncan's multiple range tests and descriptive statistics using SPSS 16 (SPSS, 2010). The least significant difference (LSD) was used to test for difference between means and significance was defined at $\mathrm{P}<0.05$. Results are reported as mean values of determinations \pm Standard deviations (SD).

\section{Results and Discussion}

\section{Changes in proximate composition}

The changes in proximate composition during ice storage of Acetes are given in (Table 1). Moisture content was observed as $83.55 \pm 0.46 \%$ and $84.33 \pm 0.19 \%$ on $0^{\text {th }}$ day and $11^{\text {th }}$ day respectively. The slight increase in the moisture content of Acetes was probably due to absorption of melt water by the muscle. 
Similar results were observed by Kirshnick et al., 2006 in case of $M$. rosenbergii stored in ice. Basavakumar et al., 1998 also observed the increase in moisture content of $P$. Monodon stored in ice. Angel et al., 1981 reported slight increase in moisture in $M$. rosenbergii kept at $0{ }^{\circ} \mathrm{C}$. The slight increase in moisture content of ice stored Acetes in present investigation is in agreement with the above findings.

Protein content of Acetes was decreased significantly ( $\mathrm{p}<0.05$ ) from $12.26 \pm 0.88$ to $10.11 \pm 0.19$ during ice storage. The loss of protein might be attributed to cell rupture during ice storage (Bauer and Eitenmiller, 1976). According to Basavakumar et al., 1998 the decrease in muscle protein observed in $P$. monodon after 7 days of storage on ice may be due to the leaching of components soluble in water and to the dilution effect for water absorption.

The fat content in fresh Acetes was very less i.e. $0.60 \pm 0.03 \%$, the slight decrease $(0.31 \pm 0.01 \%)$ in fat content might be attributed to increase in moisture content of Acetes. Similar results were observed by Kirshnick et al., 2006.

Similarly ash content was reduced from $2.24 \pm 0.02 \%$ to $2.02 \pm 0.07 \%$. However, the decrease in ash content was negligible. The slight reduction in the ash content might be attributed to leaching of soluble compounds due to loss of the natural impermeability of prawn muscle and the absorption of melt water from the ice. Kirshnick et al., 2006 reported slight reduction in the ash content of $M$. rosenbergii stored in ice.

\section{Changes in biochemical indices}

All the biochemical indices i.e. TMA, TVB-N, $\mathrm{PV}$, TBARS and $\mathrm{pH}$ were found to be increasing significantly $(\mathrm{p}<0.05)$ in Acetes during ice storage up to 11 days and are mentioned in (Table 2). TMA value increased from $3.73 \mathrm{mg} \%$ to $13.53 \mathrm{mg} \%$ during 11 days period of ice storage. It is now well established that TMA is produced mainly by bacterial action on its oxide. TMA is used to access the freshness in marine fish. Increase in TMA in P. merguinsis store in ice was found by Fatima et al., 1988. Similarly many researchers have observed direct correlation between bacterial growth and TMA production during the storage of fish product. The present increase of TMA in Acetes during ice storage can be very well correlated with above findings. Maximum acceptable limit of TMA of marine product is reported to be 15 $\mathrm{mg} \mathrm{N} \%$. The value of TVB-N increased from $5.13 \mathrm{mg} \%$ on day 0 to $21.07 \mathrm{mg} \%$ on $11^{\text {th }}$ day of ice storage of Acetes.

TVB-N includes mainly ammonia bases like dimethylamine, trimethylamine and probably traces of monoethylamine and propylamine (Contreras-Guzmán, 1994). Leitao and Rios, 2000 reported TVB-N content of $18.7 \mathrm{mg} \%$ in fresh M.rosenbergii and $26 \mathrm{mg} \%$ after 10 days of storage in ice. However, Karthikeyan et al., 1999 observed decrease in TVB-N content in $P$. indicus from $13.5 \mathrm{mg} \mathrm{N} \%$ to 37 mg $\mathrm{N} \%$. The value of TVB-N obtained in the present investigation after 11 days of ice storage are in accordance with the acceptable limit for fish and general i.e. $35 \mathrm{mg} \mathrm{N} / 100 \mathrm{~g}$ (Brasil, 1997).

PV of fresh Acetes increased from 0.83 meq peroxide $\mathrm{O}_{2} / \mathrm{kg}$ fat to 10.5 meq peroxide $\mathrm{O}_{2} / \mathrm{kg}$ fat during $11^{\text {th }}$ day of ice storage. The increase in PV in the present study might be attributed to the oxidation of unsaturated fatty acids in the Acetes. The increase in PV in the flesh cooked farm salmon up to 5 days of chilling was observed by Rodriguez et al., 2007. TBARS value of fresh Acetes increased from $0.03 \mathrm{mg} \mathrm{MDA} / \mathrm{kg}$ to $0.34 \mathrm{mg} \mathrm{MDA} / \mathrm{kg}$ during 11days of ice storage. 
Table.1 Changes in proximate composition (\%) during iced storage study of Acetes

\begin{tabular}{c|c|c|c|c|}
\hline $\begin{array}{c}\text { Storage period } \\
\text { (Days) }\end{array}$ & Moisture & Crude protein & Fat & Ash \\
\hline 0 & $83.55 \pm 0.46^{\mathrm{a}}$ & $12.26 \pm 0.88^{\mathrm{a}}$ & $0.60 \pm 0.03^{\mathrm{a}}$ & $2.24 \pm 0.02^{\mathrm{a}}$ \\
\hline 3 & $83.66 \pm 0.51^{\mathrm{a}}$ & $12.16 \pm 0.34^{\mathrm{ab}}$ & $0.58 \pm 0.05^{\mathrm{a}}$ & $2.23 \pm 0.04^{\mathrm{a}}$ \\
\hline 6 & $83.82 \pm 0.30^{\mathrm{a}}$ & $11.53 \pm 0.29^{\mathrm{bc}}$ & $0.49 \pm 0.03^{\mathrm{b}}$ & $2.14 \pm 0.049^{\mathrm{b}}$ \\
\hline 9 & $83.99 \pm 0.78^{\mathrm{a}}$ & $10.81 \pm 0.91^{\mathrm{cd}}$ & $0.34 \pm 0.03^{\mathrm{c}}$ & $2.11 \pm 0.092^{\mathrm{c}}$ \\
\hline 11 & $84.33 \pm 0.19^{\mathrm{a}}$ & $10.11 \pm 0.19^{\mathrm{d}}$ & $0.31 \pm 0.01^{\mathrm{c}}$ & $2.02 \pm 0.07^{\mathrm{c}}$ \\
\hline
\end{tabular}

Different letters in the same column indicate the significant difference $(\mathrm{p}<0.05)$. Values are mean $\pm \mathrm{SD}(\mathrm{n}=3)$.

Table. 2 Changes in biochemical indices during iced storage study of Acetes

\begin{tabular}{|c|c|c|c|c|c|}
\hline $\begin{array}{l}\text { Storage period } \\
\text { (Days) }\end{array}$ & $\begin{array}{l}\text { TMA } \\
\text { (mg N/100g) }\end{array}$ & $\begin{array}{l}\text { TVBN } \\
(\mathrm{mg} \mathrm{N} / 100 \mathrm{~g})\end{array}$ & $\begin{array}{l}\text { PV (meq of } \\
\mathrm{O}_{2} / \mathrm{kg} \text { of fat) }\end{array}$ & $\begin{array}{l}\text { TBARS (mg } \\
\text { malonaldehyde/kg) }\end{array}$ & $\mathrm{pH}$ \\
\hline 0 & $3.73 \pm 0.81^{\mathrm{a}}$ & $5.13 \pm 1.40^{\mathrm{a}}$ & $0.83 \pm 0.06^{\mathrm{a}}$ & $0.03 \pm 0.00^{\mathrm{a}}$ & $6.56 \pm 0.01^{\mathrm{a}}$ \\
\hline 3 & $6.85 \pm 0.80^{\mathrm{ab}}$ & $7.77 \pm 1.58^{\mathrm{a}}$ & $1.53 \pm 0.26^{\mathrm{a}}$ & $0.20 \pm 0.01^{\mathrm{a}}$ & $6.78 \pm 0.01^{\mathrm{a}}$ \\
\hline 6 & $9.31 \pm 0.81^{b}$ & $11.33 \pm 2.38^{b}$ & $7.67 \pm 0.29^{b}$ & $0.21 \pm 0.01^{\mathrm{a}}$ & $7.25 \pm 0.01^{b}$ \\
\hline 9 & $11.42 \pm 0.79^{\mathrm{bc}}$ & $17.34 \pm 1.30^{\mathrm{bc}}$ & $9.00 \pm 1.30^{\mathrm{bc}}$ & $0.29 \pm 0.01^{\mathrm{a}}$ & $7.62 \pm 0.02^{b}$ \\
\hline 11 & $13.53 \pm 0.47^{b c}$ & $21.07 \pm 1.36^{\mathrm{c}}$ & $10.50 \pm 0.50^{\mathrm{bc}}$ & $0.34 \pm 0.01^{\mathrm{a}}$ & $8.09 \pm 0.02^{b c}$ \\
\hline
\end{tabular}

Different letters in the same column indicate the significant difference $(\mathrm{p}<0.05)$. Values are mean $\pm \mathrm{SD}(\mathrm{n}=3)$.

Table.3 Changes in fatty acid profile during ice storage study of Acetes

\begin{tabular}{|l|l|l|l|}
\hline Name & Short illustration & $\begin{array}{l}\text { Area } \\
\mathbf{0}^{\text {th }} \text { Day }\end{array}$ & $\mathbf{9}^{\text {th }}$ Day \\
\hline Lauric acid & C12:0 & 0.17 & 0.59 \\
\hline Tridecanoic acid & C13:0 & 4.37 & 0.09 \\
\hline Myristic acid & C14:0 & 0.35 & 7.12 \\
\hline Pentadecanoic acid & C15:0 & 1.3 & 1.87 \\
\hline Palmitic acid & C16:0 & 23.09 & 29.29 \\
\hline Margaric acid & C17:0 & 2.12 & 2.82 \\
\hline Stearic acid & C18:0 & 4.02 & 1.53 \\
\hline Eicosanoic acid & C20:0 & 0.83 & 0.59 \\
\hline Docosanoic acid & C22:0 & 1.22 & 2.55 \\
\hline SAFA & & $\mathbf{3 7 . 4 7}$ & $\mathbf{4 6 . 4 5}$ \\
\hline Palmitoleic acid & C16:1(n-7) & 24.25 & 22.24 \\
\hline Oleic acid & C18:1(n-9) & 7.18 & 4.75 \\
\hline Gadoleic acid & C20:1(n-9) & 0.77 & 3.46 \\
\hline Erucic acid & C22:1(n-9) & 0.3 & 0.79 \\
\hline MUFA & & $\mathbf{3 2 . 5}$ & $\mathbf{3 1 . 2 4}$ \\
\hline Linoleic acid & C18:2(n-6) & 0.81 & ND \\
\hline Octadecadienoic acid & C18:2(n-3) & 0.22 & ND \\
\hline Ecosadienoic acid & C20:2(n-7) & 0.52 & ND \\
\hline a-Linolenic acid & C18:3(n-3) & 0.58 & 0.31 \\
\hline Arachidonic acid & C20:4(n-6) & 4.97 & 5.08 \\
\hline Ecosapentaenoic acid & C20:5(n-3) & 10.14 & 8.5 \\
\hline Docosahexaenoic acid & C22:6(n-6) & 12.83 & 8.43 \\
\hline PUFA & & $\mathbf{3 0 . 0 7}$ & $\mathbf{2 2 . 3 2}$ \\
\hline & & & \\
\hline
\end{tabular}


Table.4 Changes in Mineral profile of Acetes during ice storage

\begin{tabular}{|l|l|l|}
\hline Mineral content & $0^{\text {th }}$ Day & $9^{\text {th }}$ Day \\
\hline Cadmium (ppm) & BDL & BDL \\
\hline Copper (ppm) & 7.41 & 16.49 \\
\hline Iron (ppm) & 130.99 & 85.23 \\
\hline Zinc (ppm) & 35.83 & 46.18 \\
\hline Phosphorous (\%) & 1.89 & 1.56 \\
\hline Calcium (\%) & 3.45 & 2.88 \\
\hline Potassium (\%) & 0.25 & 0.18 \\
\hline Magnesium (\%) & 0.47 & 0.42 \\
\hline Sodium $(\%)$ & 0.92 & 0.82 \\
\hline
\end{tabular}

BDL: Below Detection Limit

Table.5 Microbial changes during ice storage study of Acetes

\begin{tabular}{|l|l|}
\hline Storage period (Days) & TPC $(\mathbf{c f u} / \mathbf{g})$ \\
\hline $\mathbf{0}$ & $1.42 \times 10^{5}$ \\
\hline 3 & $2.66 \times 10^{5}$ \\
\hline 6 & $2.84 \times 10^{5}$ \\
\hline 9 & $3.50 \times 10^{5}$ \\
\hline 11 & $3.66 \times 10^{5}$ \\
\hline
\end{tabular}

$\mathrm{cfu}=$ colony forming units

Table.6 Sensory changes during ice storage study of Acetes

\begin{tabular}{|l|l|l|l|l|l|}
\hline $\begin{array}{l}\text { Storage } \\
\text { period (Days) }\end{array}$ & Colour & Appearance & Texture & Odour & $\begin{array}{l}\text { Overall } \\
\text { Acceptability }\end{array}$ \\
\hline $\mathbf{0}$ & $8.27 \pm 0.47^{\mathrm{a}}$ & $8.41 \pm 0.58^{\mathrm{a}}$ & $8.09 \pm 0.52^{\mathrm{a}}$ & $8.57 \pm 0.52^{\mathrm{a}}$ & $8.55 \pm 0.47^{\mathrm{a}}$ \\
\hline $\mathbf{3}$ & $8.06 \pm 0.68^{\mathrm{a}}$ & $8.31 \pm 0.80^{\mathrm{a}}$ & $7.75 \pm 0.65^{\mathrm{b}}$ & $7.98 \pm 0.08^{\mathrm{b}}$ & $8.31 \pm 0.64^{\mathrm{a}}$ \\
\hline 6 & $7.88 \pm 0.58^{\mathrm{b}}$ & $7.81 \pm 0.65^{\mathrm{b}}$ & $7.83 \pm 0.74^{\mathrm{c}}$ & $7.81 \pm 0.65^{\mathrm{bc}}$ & $7.81 \pm 0.59^{\mathrm{b}}$ \\
\hline 9 & $7.11 \pm 0.70^{\mathrm{bc}}$ & $6.72 \pm 0.67^{\mathrm{b}}$ & $6.61 \pm 0.42^{\mathrm{c}}$ & $7.00 \pm 0.61^{\mathrm{bc}}$ & $7.28 \pm 0.26^{\mathrm{b}}$ \\
\hline 11 & $6.01 \pm 0.52^{\mathrm{c}}$ & $5.72 \pm 0.45^{\mathrm{b}}$ & $5.98 \pm 0.34^{\mathrm{c}}$ & $6.90 \pm 0.61^{\mathrm{c}}$ & $6.32 \pm 0.46^{\mathrm{c}}$ \\
\hline
\end{tabular}

Different letters in the same column indicate the significant difference $(\mathrm{p}<0.05)$. Values are mean \pm SD $(n=3)$.

Table.7 Sensory changes during ice storage study of cooked Acetes

\begin{tabular}{|c|l|l|l|l|l|l|}
\hline $\begin{array}{l}\text { Storage } \\
\text { period (Days) }\end{array}$ & Colour & Appearance & Texture & Taste & Odour & $\begin{array}{l}\text { Overall } \\
\text { Acceptability }\end{array}$ \\
\hline 0 & $8.60 \pm 0.52^{\mathrm{a}}$ & $8.60 \pm 0.52^{\mathrm{a}}$ & $8.10 \pm 0.70^{\mathrm{a}}$ & $8.53 \pm 0.53^{\mathrm{a}}$ & $8.05 \pm 0.60^{\mathrm{a}}$ & $8.65 \pm 0.47^{\mathrm{a}}$ \\
\hline 3 & $8.25 \pm 0.53^{\mathrm{a}}$ & $7.69 \pm 0.59^{\mathrm{b}}$ & $7.88 \pm 0.83^{\mathrm{a}}$ & $7.15 \pm 0.46^{\mathrm{ab}}$ & $7.88 \pm 0.58^{\mathrm{b}}$ & $8.00 \pm 0.60^{\mathrm{b}}$ \\
\hline 6 & $7.69 \pm 0.53^{\mathrm{ab}}$ & $7.81 \pm 0.46^{\mathrm{b}}$ & $7.56 \pm 0.42^{\mathrm{a}}$ & $7.50 \pm 0.46^{\mathrm{ab}}$ & $7.63 \pm 0.52^{\mathrm{bc}}$ & $7.94 \pm 0.23^{\mathrm{ab}}$ \\
\hline 9 & $7.00 \pm 0.56^{\mathrm{b}}$ & $7.17 \pm 0.50^{\mathrm{b}}$ & $7.11 \pm 0.6^{\mathrm{b}}$ & $7.39 \pm 0.49^{\mathrm{bc}}$ & $7.22 \pm 0.26^{\mathrm{bc}}$ & $7.28 \pm 0.57^{\mathrm{bc}}$ \\
\hline 11 & $6.90 \pm 0.48^{\mathrm{c}}$ & $6.34 \pm 0.93^{\mathrm{c}}$ & $6.20 \pm 0.59^{\mathrm{b}}$ & $6.93 \pm 0.76^{\mathrm{c}}$ & $6.34 \pm 0.87^{\mathrm{c}}$ & $6.98 \pm 0.45^{\mathrm{c}}$ \\
\hline
\end{tabular}

Different letters in the same column indicate the significant difference $(\mathrm{p}<0.05)$. Values are mean \pm SD $(n=3)$. 
This is probably due to the oxidation of polyunsaturated fatty acids from the muscles caused by the presence of oxygen inside the plastic bag. According to Srinivasan et al., 1966, when the prawn shell is removed, superficial tissues damaged and an important barrier against oxygen is lost.

$\mathrm{pH}$ value of Acetes increased from 6.56 to 8.09 during ice storage up to $11^{\text {th }}$ day. The increase in $\mathrm{pH}$ value indicates the protein degradation which produces alkaline substances such as ammonia and other amines. The increase in $\mathrm{pH}$ value in the present investigation can be very well correlated with the increase in TMA and TVB-N values. Kirshnick et al., 2006 also reported increase in $\mathrm{pH}$ of $M$. rosenbergii during ice storage up to 14 days. Similarly Nip et al., 1985 also observed a significant increase in muscle $\mathrm{pH}$ of whole $M$. rosenbergii stored in ice.

\section{Changes in fatty acid profile}

Although the fat content in fresh Acetes was found to be very less i.e. $0.60 \%$, their fatty acid profiles have shown some interesting findings (Table 3). The sum of SAFA was found to be $37.47 \%$, MUFA $32.5 \%$ and PUFA were $30.07 \%$ in fresh Acetes at day 0 of ice storage study. Emami et al., (2014) reported sum of SFA, MUFA and PUFA as $37.26 \%, 24.9 \%$ and $37.84 \%$ respectively in $P$. Vannamei shrimp. Similarly Emami et al., 2014 also reported the presence of $49.12 \%$ FA, $33.76 \%$ MUFA and $16.9 \%$ of PUFA in $P$. semisulcatus shrimp. Balch, (2011) reported that $100 \mathrm{~g}$ steamed cooked shrimp contains SFA of about $396.1 \mathrm{mg}$. Turan et al., 2011 reported SFA in brown colour shrimp to be about $33.04 \%$.The essential fatty acids i.e. EPA and DHA were found in good amount in fresh Acetes i.e. $10.14 \%$ and $12.83 \%$ respectively. On the $9^{\text {th }}$ day of ice storage SFA was found to be $46.45 \%$, MUFA was
$31.41 \%$ and PUFA was reduced from $30.07 \%$ to $22.32 \%$ on $9^{\text {th }}$ day of ice storage. Some of the MUFA i.e. Linoleic acid, Octadecadienoic acid, Ecosadienoic acid were not detected after $9^{\text {th }}$ day of ice storage. The changes in fatty acid profile of Acetes during ice storage might be attributed to enzymatic and bacterial activity. Oxidation of fats especially unsaturated fatty acids could be the reason for the loss of some of the MUFA. This can be very well correlated with the increased value of PV and TBARS value of Acetes during ice storage and both are the indicators of primary and secondary oxidations of fat.

\section{Changes in mineral profile}

Heavy metal like cadmium was not detected in Acetes (Table 4). However essential minerals like $\mathrm{Cu}, \mathrm{Fe}, \mathrm{Zn}, \mathrm{P}, \mathrm{Ca}, \mathrm{K}, \mathrm{Mg}$ and $\mathrm{Na}$ were reported in good proportion. Yanar and Celik, (2004) reported the presence of $\mathrm{Ca}$, $\mathrm{P}, \mathrm{Na}$ and $\mathrm{Fe}$ in green tiger shrimp. The minerals like $\mathrm{Fe}, \mathrm{Zn}, \mathrm{P}, \mathrm{Cs}$ and $\mathrm{Na}$ in the Acetes were found to be decreased on $9^{\text {th }}$ day of ice storage. This decrease in mineral might be attributed to the leaching out effect during ice storage.

\section{Microbial changes}

From the results it was observed that total plate count in Acetes increased gradually from $1.42 \times 10^{5} \mathrm{cfu} / \mathrm{g}$ to $3.66 \times 10^{5} \mathrm{cfu} / \mathrm{g}$ (Table 5) during 11 days of ice storage. This gradual increase may be attributed to the long adoption period for pscychrotrophs during ice storage. Kirshnick et al., (2006) also reported a gradual increase of bacterial count in ice stored $M$. rosenbergii. Zeng et al., (2005) reported that total viable counts of shrimp $(P$. borealis) increased during different ice stored conditions. This increase in total plate count of Acetes during ice storage can be very well correlated with the increase in TVB-N and TMA values in the present investigation. 
However TPC values of Acetes were very well within the acceptable limit on $11^{\text {th }}$ day of ice storage.

\section{Changes in sensory quality parameters}

Sensory changes of ice stored Acetes are given in (Table 6). From the result it was observed that sensory scores for all attributes i.e. colour, appearance, texture, odour and overall acceptability were reduced steadily during the 11 days of ice storage of Acetes. This reduction can be very well correlated with the increase value of TMA, TVB-N, PV, TBARS and $\mathrm{pH}$ of Acetes during 11 days of ice storage. Similar results were obtained by Zeng et al., 2005 who reported decrease in sensory scores of shrimp (P. borealis) during ice storage study. Further, Jeyasekaran et al., 2006 also reported decrease in sensory score for Indian white shrimp ( $P$. indicus) stored in dry ice. Similar pattern was observed for sensory scores of cooked Acetes during ice storage (Table 7). Nevertheless, the scores for both fresh as well as cooked Acetes were within the acceptable limit on the $11^{\text {th }}$ day of ice storage. From the results of the present investigation, it can be concluded that Acetes can be stored in iced condition up to 11 days.

\section{Acknowledgements}

The first author is thankful to Indian Council of Agricultural Research (ICAR) and Director, Central Institute of Fisheries Education, Mumbai for providing necessary facilities for conducting this study. The first author also remains grateful to all the staff members of the Post-Harvest Technology Division, ICAR-CIFE, Mumbai.

\section{References}

Angel, S., Basker, D., Kanner, J., and Juven, B. J., 1981. Assessment of shelf-life of freshwater prawns stored at $0^{\circ} \mathrm{C}$. J. Food Technol. 16: 357-366.
Angel, S., Weinberg, Z. G., Juven, B. J., and Lindner, P., 1985. Quality changes in the fresh water prawns, Macrobrachium rosenbergii during storage on ice. J. Food Technol., 20: 553- 560.

Anon, 2013. Annual Report 2012-13. CMFRI, Cochin: 200p.

AOAC, 1995. Official methods of analysis $16^{\text {th }}$ Edn. Association of official analytical chemists. Washington DC, USA.

AOAC, 2000. Official Methods of Analysis of AOAC International $17^{\text {th }}$ Edn. Suite 500, 481 North Frederick Avenue, Gaithersburg, Maryland 20877-2417 USA.

AOAC, 2005. Official Methods of Analysis $\left(18^{\text {th }}\right.$ Edn) Association of Official Analytical Chemists Gaithersburg, Maryland 208772417 USA PP 270-310

APHA, 2001. Compendium of methods for the microbiological examination of foods. American Public Health Association, New York.

Balch, Phyllis, 2011. Prescription for Nutritional Healing, $5^{\text {th }}$ Edition: A Practical A-to-Z Reference to Drug-Free Remedies Using Vitamins, Minerals, Herbs \& Food... A-To$\mathrm{Z}$ Reference to Drug-Free Remedies. Published by the Penguin Group.USA Inc., New York, P: 869

Basavakumar, K.V., Bhaskar, N., Ramesh, A. M., and Reddy, G. V. S., 1998. Quality changes in cultured tiger shrimp (Penaeus monodon) during ice storage. J. Food Sci. Technol. 35(4): 305-309.

Bauer, B. A., and Eitenmiller, R. R., 1976. A study of some kinetic properties of partial purified Penaeus setiferus aryl amidae. J. Food Sci. 39: 10-14.

Brasil, Ministério, Da. Agricultura, Pecuária. E. Abastecimento. Legislação de Pescadoe Derivados, Brasília, 1997. Portaria n.185, de 13 de maio de, Diário Official da União 19 de maio de.

Contreras-Guzmán, E. S., 1994. Bioquímica de pescados e derivados, 409 p., FUNEP,

Emami, S. M., Abbas, M., Abolghasem, K., and Mehdi, S., 2014. Fatty Acid and Amino Acid Composition of Marine (Penaeus semisulcatus) and Farmed (Penaeus vannamei) Shrimp Species from Bushehr, Iran J. Appl. Environ. Biol. Sci. 4(4)262- 
270.

Fatima, R., Khan, M. A., Quadri, K., and Qadri, R. B., 1988. Shelf life of shrimp (Penaeus merguiensis) stored in ice and partially frozen $\left(-3^{\circ}\right.$ C). J. Sci. Food Agric. 42: 235 247.

Jeyasekaran, G., Ganesan, P., Anandarai, R., Jeya Shakila, R., and Sukumar, D., 2006. Quantitative and qualitative studies on the bacteriological quality of Indian white shrimp (Penaes indicus) stored in dry ice. Journal of Food Microbiol. 23(6):526-33.

Karthikeyan, M., Jawahar-Abraham, T., Shanmugam, S.A., Indra-Jasmine, G., and Jeyachandran, P., 1999. Effect of washing and chlorine disinfection on the quality and shelf-life of iced cultured shrimp. J. Food Sci. Technol. 36(2): 173-176.

Kirshnick, P. G., Elisabete, M. M. V., Wagner, C. V., and Carlos, A. F. de Oliveira., 2006. Shelf-life of tail meat of the giant river prawn, Macrobrachium rosenbergii, Journal of Aquatic Food Product Technology, 15: 57-71.

Leitao, M. F. F., and Rios, D. P., 2000. Microbiological and chemical changes in freshwater prawn (Macrobrachium rosenbergii) stored under refrigeration. Brazilian J. Microbio. 31: 178-183.

Nip, W. K., Moy, J. H., and Tzang, Y. Y., 1985. Effect of purging on quality changes of icechilled freshwater prawns, Macrobrachium rosenbergii. J. Food Technol. 20: 9-15.

Rodriguez A., Losada, V., Larrain, Ma. A., Quitral, V., Vinagre, J., and Aubourg, S., 2007. Development of lipid changes related to quality loss during the frozen storage of farmed Coho salmon (Oncorhynchus kisutch).Journal of Aquatic Food Product Technology, 84:727-34.
SPSS, 2010. SPSS for windows. Release 16. Chicago, 1: SPSS Inc.

Sridhar, R. 1983. Biochemical aspects of dried Acetes. M.Sc. Thesis, University of Mumbai, India.

Srinivasan, R., Jayachandran, P., and Pitehaiah, P., 1966. On the canning of Sardinella fimbriata, Sardinella gibbosa and Sardinella sirm in oil pack. Journal of Fish. Technol. 3 (2): 118-123.

Tarladgis, B. G., Watts, B. M., Younathan, M. T., and Dugan Jr, L., 1960. A distillation method for the quantitative determination of malonaldehyde in rancid foods. $J A M$. Oil Chem. Soc. 37(1): 44-48.

Turan, Hülya, Yalçin, Kaya, and Emin Erdem, M., 2011. Proximate Composition, Cholesterol, and Fatty Acid Content of Brown Shrimp (Crangon crangon L. 1758) from Sinop Region, Black Sea. Journal of Aquatic Food Product Technology. 20(1), 100-107.

Vyncke, W., 1996. Comparison of the official EC method for the determination of total volatile bases in fish with routine methods. Arch. Lebensmittelhyg., 47, 110-111.

Yanar, Y., Celik, M., and Yanar, M., 2004. Seasonal changes in total carotenoid contents of wild marine shrimps (Penaeus semisulcatus and Metapenaeus monoceros) inhabiting the eastern Mediterranean. Journal of Food Chemistry. 88, 267-269.

Zeng, Q. Z., Kristin, A. T., and Gudrun, O., 2005. Quality Changes of Shrimp (Pandalus borealis) stored under different cooling conditions. Journal of Food Science. 70 (7).

Zynudheen, A., Ninan, G., Sen, A., and Badonia, R., 2004a. Processing and utilization of Acetes (Jawla prawn). CIFT Technology Advisory Series. 15:1-6.

\section{How to cite this article:}

Utkarsha Keer, Hina Alim, Martin Xavier and Balange, A.K. 2018. Quality Changes during Ice Storage of Acetes species. Int.J.Curr.Microbiol.App.Sci. 7(01): 2063-2071. doi: https://doi.org/10.20546/ijcmas.2018.701.248 